\section{Psicoterapias cognitiva e construtivista: novas fronteiras da prática clínica}

Cristiano Nabuco de Abreu, Miréia Roso e colaboradores. Porto Alegre: Artmed, 2003. ISBN 85-363-0107-4

A história da terapia comportamental e cognitiva tem sido contada por vários autores. O mais comum é encontrarmos que a terapia comportamental e cognitiva teve sua origem no movimento filosófico denominado "neo-behaviorismo". Por essa razão, autores como Watson (apontado como o fundador do movimento behaviorista), Tolman e Hull (iniciadores do behaviorismo mediacional), e Skinner (proponente do behaviorismo radical) são tidos como precursores de toda e qualquer psicoterapia que leve o adjetivo "comportamental" em seu nome. ${ }^{1}$

Desde as que procuram listar uma série de técnicas até aquelas que encaram a psicoterapia enquanto processo, das mais estruturalistas às funcionalistas, das mecanicistas às contextualistas, das dualistas às monistas, toda uma gama de psicoterapias "comportamentais" pode ser encontrada na literatura. ${ }^{2}$ Foram identificados nada menos do que 28 termos para se referir à terapia comportamental na literatura produzida no Brasil entre 1970 e $2001 .^{3}$

Por essa razão, uma proposta como a contida na obra "Psicoterapias cognitiva e construtivista: novas fronteiras da prática clínica" só pode ser comemorada. O psicoterapeuta deve ser estimulado a exercitar o olhar para si e para sua prática, além de ser dirigido para o contato com as origens de sua área de conhecimento.

O livro cumpre esse papel. Sua estrutura é bastante interessante, instigante e didática. Enquanto busca traçar as origens históricas comuns das abordagens focalizadas em seu título (cognitiva e construtivista), pontua as divergências observadas entre as duas na teoria e na prática. As diferenças são tão marcantes que os organizadores chegam a sinalizar que a adequação das abordagens varia de caso para caso, conforme pode ser observado na introdução (páginas 14 e 15) - o que em si já denota o caráter tecnicista das propostas apresentadas.

O percurso histórico, no entanto, é bastante parcial e peculiar (pode-se dizer até interpretativo) como todo recorte histórico. Por exemplo, os organizadores localizam que a "revolução cognitiva teve início por volta de 1956, quando Skinner começou a incluir o comportamento verbal como tema de seus estudos" (pág. 13). A leitura dessa frase poderia induzir à conclusão de que Skinner deu o grande salto (ou o mote) para a revolução cognitiva, enquanto se sabe que Skinner nada teve a ver com tal revolução. Foram exatamente Tolman, desde 1932, e Hull, desde 1943, que desenvolveram os trabalhos que fundamentariam de modo mediacionista a explicação do comportamento. ${ }^{1}$ Ainda

\section{Referências}

1. Costa N. Terapia analítico-comportamental: dos fundamentos filosóficos à relação com o modelo cognitivista. Santo André: ESETec Editores Associados; 2001.

2. Dougher MJ, Hayes S. Clinical behavior analysis. In: Dougher MJ, ed. Clinical behavior analysis. Reno: Context Press; 1999. p. 11-25. assim, Hull preparou o terreno para o cognitivismo fisicalista (abordado hoje em dia pelas neurociências), e Tolman criou as condições para o desenvolvimento do cognitivismo propriamente dito, tanto o objetivista quanto o construtivista.

A estrutura do livro inicia com os aspectos epistemológicos das abordagens confrontadas, apresentando em seu capítulo introdutório os elementos comuns que deram origem a

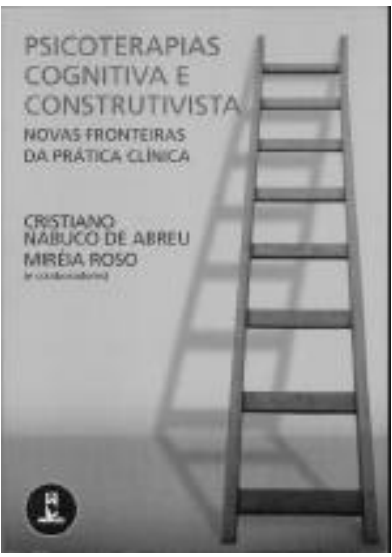
elas. Em seguida, procura delinear as diferenças entre as práticas dos dois tipos de profissional. Esta linha comparativa que acompanha todo o desenrolar das seções apresentadas no livro propicia um conhecimento maior para qualquer psicoterapeuta sobre sua prática atual. Auxilia-o também na identificação e reconhecimento (e até mesmo na escolha) de uma prática que melhor condiga com suas próprias crenças e preferências.

Os autores, tanto profissionais cognitivistas quanto construtivistas, alguns reconhecidos em obras clássicas internacionais, outros não tão reconhecidos ainda, utilizaram como base a descrição cuidadosa de suas práticas perante os problemas mais freqüentes do dia-a-dia das pessoas que procuram psicoterapia. Não à toa, a depressão, os transtornos ansiosos (fobia social, transtorno de pânico, transtorno obsessivo-compulsivo), transtornos alimentares, a dependência química e a terapia de casal foram "pinçados" para o foco de análise.

O foco principal dos artigos é sempre a teoria, sem esquecer em momento algum sua aplicabilidade.

Um destaque especial é apresentado à seção intitulada "Novas fronteiras da prática clínica", contida inclusive no título do livro. Nessa seção, os autores buscam chegar aos limites do que já se conhece, numa corajosa abordagem de "temas-tabu": a ruptura do processo terapêutico; a empatia; a religião; a cultura organizacional e a oncologia. Realizam também uma análise que focaliza o psicoterapeuta enquanto pessoa.

Os textos apresentados nessa seção podem ser considerados como uma referência segura e criativa, apontando o quanto ainda há por vir de trabalho sério, comprometido, consciente.

Estas características tornam o livro um excelente guia teórico-prático.

Roberto Alves Banaco

Departamento de Métodos e Técnicas da Faculdade de Psicologia da Pontifícia Universidade Católica de São Paulo

3. Nolasco NC. A evolução do conceito de intervenção clínica comportamental conforme apresentada em artigos produzidos no Brasil: uma revisão histórica [dissertação de mestrado]. São Paulo: Pontifícia Universidade Católica de São Paulo; 2002. 